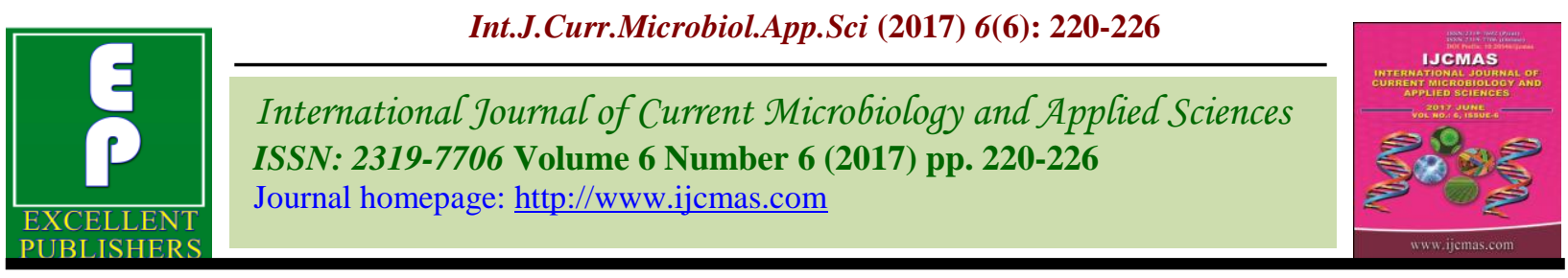

Review Article

https://doi.org/10.20546/ijcmas.2017.606.026

\title{
Nutrition Security Status in India - Impediments, Remedies and Way Forward
}

\author{
L. Muralikrishnan ${ }^{1}$, K.C. Sivabalan ${ }^{2 *}$, V. Sangeetha ${ }^{1}$ and Premlata Singh ${ }^{1}$ \\ ${ }^{1}$ Division of Agricultural Extension, IARI, New Delhi-12, India \\ ${ }^{2}$ PRIST University, Tanjore, Tamil Nadu, India \\ *Corresponding author
}

\section{A B S T R A C T}

India is likely to be the most populous country in the planet by 2030 with 1.6 billion people. It currently accounts for more than $17 \%$ of the global population and 456 million poor, or $41.6 \%$ living on less than $\$ 1.25$ a day. Among all problems in India, providing nutritional security to all peoples is the main problem. Nutritional insecurity is the problem

Keywords through "nutrition gap," it is between what foods are consumed and what foods are needed for good nutrition. Good health depends on good nutrition. Good nutrition, in turn,

Agriculture,

Malnutrition,

Health,

Nutritional

security

Article Info

Accepted:

04 May 2017

Available Online:

10 June 2017 depends on agriculture to provide the foods - cereals, pulses, vegetables, fruit, meat, fish, milk and dairy products - for a balanced diet that meets our needs for energy, protein, vitamins and minerals. Nutrition is the bridge between agriculture and health. Nutritional security should be achieved through not only the quantity food items mainly quality food products. This review paper deals about important strategies to improve the nutrition security in India such as promotion of industrial fortified products, promotion of homestead gardening practices, snacks based food supplements for women of childbearing age, enhancement of diversified agricultural production, empowerment of rural women, strengthening the links between the agriculture -nutrition and health sectors, providing nutrition education, ground water improvement climate change mitigation in agriculture for sustainable production, development of infrastructures in marginalized areas. And, it suggests that even though India has many policies to control the food insecurity and malnutrition. The focus of reforms should now be shifted to more efficient delivery systems and transformation of nutrient rich agricultural production and distribution process.

\section{Introduction}

Malnutrition is the world's most serious health problem and the single biggest contributor to child deaths. One third of the developing world's population suffers micronutrient deficiencies that can lead to blindness, mental retardation and early death. The strategic framework of FAO's first goal is reducing the number of hungry and ensuring adequate nutrition for all between the periods of 2010-2019. With respect to India, India is likely to be the most populous country in the planet by 2030 with 1.6 billion people. It currently accounts for more than $17 \%$ of the global population and 456 million poor, or $41.6 \%$ living on less than $\$ 1.25$ a day (Chen and Ravallion, 2008). According to Food and Agriculture Organization (FAO), Food security has three components, viz., 
availability, access, and absorption (nutrition). It suggests that the nutritional security is the only solution to solve the malnutrition and health issues. But, About 75 percent of the India's poor and hungry live in rural areas and depend on agriculture as their primary source of food, employment and income (FAO, 2009b).

In order to tackle widespread problems of nutrition, it might be necessary to move scaling up "nutrition-specific" interventions (i.e., those that address the immediate determinants of nutrition) and devote "new and aggressive focus on coupling effective nutrition-specific intervention with nutrition sensitive interventions" that address the underlying causes of under nutrition.

\section{Nutritional insecurity}

Nutritional insecurity is the problem through "nutrition gap," it is between what foods are consumed and what foods are needed for good nutrition. Even if there is availability as well as access to food, there is no guarantee of adequate absorption or nutrition, especially since, nutrition depends on many other factors such as the condition of pregnant women, breast feeding, health factors, hygiene, drinking water, sanitation, etc. And so, access to health care and sanitation facilities is among the key determinants of nutrition security.

The under nutrition is the result of not having enough to eat the quality of diets, such as lack of protein and of micronutrients, including iron, iodine, zinc and vitamin A. Micronutrient malnutrition (or "hidden hunger") affects people and can lead to poor physical growth and development, lowered mental capacity, reduced productivity, impaired immune systems and other health problems (FAO, 2010)

\section{Tribulations of nutritional security in India}

It is now well recognized that India's economic growth is good. But the problem of persistent and widespread under nutrition, poverty and rising inequalities also increasing in absolute quantities (Drèze and Sen, 2013). The economic growth and its importance, cannot alone deliver nutritional security. It requires specific interventions to address nutritional problems through "nutritionsensitive" food and agriculture protection for promoting food and nutrition security. Economic access to food by about a one fourth of the population living below the poverty line is problematic.

The level of malnutrition especially among women and children remains unacceptably high. About $44 \%$ of children under the age of 5 are underweight around half of pregnant women are anemic condition.

Good health depends on good nutrition. Good nutrition, in turn, depends on agriculture to provide the foods - cereals, pulses, vegetables, fruit, meat, fish, milk and dairy products - for a balanced diet that meets our needs for energy, protein, vitamins and minerals. Nutrition is the bridge between agriculture and health.

The important problems in agricultural sectors are the following: (i) ill effects of globalization challenges in agricultural sector, volatility in prices; (ii) shrinking farm size; (iii) dry land farming challenges; and (iv) environmental stress. And so, the six deficits in agriculture are: (i) investment, credit, and infrastructure deficit; (ii) research and extension (technology) deficit; (iii) market deficit; (iv) diversification deficit; (v) institutions deficit; and (vi) education/skill deficit. Deficiencies in agriculture and rural infrastructure are the biggest problems for agricultural development. 
Nutritional security should be achieved through much more attention needs to be given, not only to the quantity, but also to the quality of foods available and consumed, especially among low-income rural households, where monotonous diets high in starchy staples and low in micronutrients are the norm, and where adequate amounts of micronutrient-rich foods, such as meat, dairy products, legumes, vegetables and fruit, are generally unavailable.

\section{Social disparities in nutritional security}

Social disparities are main indicators of poverty and vulnerability. So, the incidence of malnutrition also increased due to the concern indicators. The SC/ST and Muslims suffer from poverty and vulnerability to a greater extent as compared to OBCs and other castes. The incidence of malnutrition (chronic energy deficiency) among women is the highest for SCs/STs, followed by OBCs and Muslims. The malnutrition among women for OBCs is much lower than other castes (Jose and Navaneetham 2010).

\section{Materials and Methods}

\section{Strategies to improve the nutrition security in India}

\section{Food-based strategies for improving} nutrition

Industrial fortified products promotion is one of the comprehensive strategy of commonly consumed food vehicles - such as iodized salt and fortified flour - and home fortification of meals using micronutrient powders and lipidbased spreads, can all play an important role in food-based nutrition interventions. A more sustainable approach, however, is bio fortification, i.e. increasing the vitamin A, iron and zinc content of staple food crops through plant breeding and improved agronomic practices. For example, improved varieties of orange-fleshed sweet potato and golden rice are very rich in beta carotene (FAO, 2011a).

However, well-designed food-based interventions - combined, with appropriate, use of supplements and supported by health and nutrition education - can improve the diets of vulnerable populations in a relatively short period of time and that those improvements are sustainable (FAO, 2011a).

\section{Homestead gardening practices}

Sustainable enhancement of household "nutritional self-sufficiency" through the establishment of homestead gardens. It supports significantly higher intake of fresh vegetables, dark green leafy vegetables, eggs and milk. It has led to a decline in the prevalence of anemia in women and in children aged from six months to five years (Arimond et al., 2011). Improved nutritional status of mothers is associated with better child health and survival. Good nutrition in the early months of pregnancy has the greatest positive impact on birth outcomes.

\section{Snack food supplements for women of child-bearing age}

India has developed and consumed a snack food consisting of fresh green leafy vegetables, milk powder and dried fruit. Among low-income women of child-bearing age, one serving of the snack more than doubles the median intake of fruit, vegetables and milk, and provides micronutrients amounting to 12 to 43 percent of average daily requirements. Trials in rural India found that mothers with adequate intakes of similar formulations at 28 weeks' gestation delivered fewer low birth-weight babies (Shivashankaran et al., 2011). 


\section{Diversify agricultural production}

A more sustainable approach for subsistence farming households is diversification of their food production through the introduction of horticultural crops, fish and livestock that are suited to local agro-ecological conditions and can fill macro- or micronutrient deficiencies in the local diet. Key strategy in nutritionsensitive agricultural development is the "food-based" approach, which is aimed at increasing the availability and consumption of the diverse range of foods necessary for a healthy diet.

The nutritional quality of the diet improves as a greater diversity of food items and food groups is consumed. Therefore, food-based interventions promote dietary diversification by increasing the availability of, access to and consumption of foods with a high content and bioavailability of nutrients throughout the year. Those foods include nutrient-rich animal-source foods, such as dairy products, poultry and fish, which address multiple nutrient deficiencies, as well as pulses, vegetables and fruit. Promotion of nutritional security programme through crops, aquaculture and livestock increases the production of nutrient-rich foods for direct consumption as well as income generation. Nutrition-sensitive diversification requires crop varieties and animal stock with enhanced nutritional quality, and post-harvest technologies that reduce food losses and conserve nutrients. They will need to be adapted to a wide range of farming systems, agro-ecological zones and diet typologies.

\section{Empower rural women}

Rural women are the strongest link between agriculture and nutrition. So, at field level, both nutrition and gender inequities need to be addressed through the design of agricultural development programmes. There is a strong positive association between rural women's empowerment and nutritional security. Women with higher status have better nutritional status themselves, are better cared for, and provide higher quality care to their families. Where inequalities between women and men are greatest, women's health and family nutritional status are poorest. If women and men had equal status, the prevalence of underweight children would decline by almost 30 percent (Jose and Navaneetham 2010).

\section{Strengthen links between the agriculture, nutrition and health sectors}

Interventions aimed at improving diets and raising levels of nutrition should combine public health, nutrition education and dietary strategies. Agriculturalists need to work with nutritionists to identify deficits in local diets and micronutrient intakes. Food-based interventions will be more effective when accompanied by community health programmes.

\section{Provide nutrition education}

Interventions should include a strong programme of nutrition education and behavior change, targeted principally towards women, in order to ensure that increases in food supply and income lead to improved household nutrition. It should be solved through the social protection programmes of food transfer through (PDS) and supplementary nutritional programmes.

\section{Ground water improvement improves the nutritional security}

India is a net agricultural exporter but food availability is threatened by the effects of declining water resources. There is a huge pressure on groundwater resources in India and this is felt even more during periods of 
drought; hence, large investments are needed in "groundwater banking" (Shah et al., 2009). It is interesting to observe that Gujarat has invested in more than 100,000 check dams through the involvement of nongovernment organizations since the year 2000, and has been instrumental in recharging water tables. This has given rich dividends to Gujarat, which has registered the highest rates of growth in agriculture (above 9\% per annum) among all states of India supportive to the decentralized food availability and nutritional security (Shah et al. 2009).

\section{Climate Change mitigation}

One of the emerging issues in food security is climate change and its impact on agriculture. The vast majority of India's population depends on climate-sensitive sectors like agriculture, forestry, and fishery for their livelihood. The adverse impact of climate change in the form of declining rainfall and rising temperatures, and thus, increased severity of drought and flooding, is bound to threaten food security and livelihoods in the economy (FAO, 2005).

\section{Development of infrastructures in marginalized areas}

In particular, women's access to clean drinking water, toilet facilities, and clean cooking fuel influences their health outcomes, which are critical to child health and nutrition. The impact is measured in terms of both the health effects and the time they spend in coping with the lack of these facilities. Over $53 \%$ of women in India do not have access to toilet facilities, $55 \%$ do not have drinking water in their premises, and only $29 \%$ have access to clean fuel. Meanwhile, $35.6 \%$ of women suffer from chronic energy deficiency, indicated by a body mass index below 18.5 (Jose and Navaneetham, 2010).

\section{Results and Discussion}

Among the poor, the most vulnerable are those whose nutritional needs are higher and social status is lowest, mainly young children, pregnant and lactating women, the sick and the elderly (UNSCN, 2010a). An estimated 40 per cent of the India's undernourished people are women (ECOSOC, 2007). Rural women are particularly vulnerable because they receive less health care and are subject to greater risks, owing to repeated pregnancies and delivery of children (FAO, 2011b).

In India, which have recorded strong economic growth over the past decade (FAO, 2010). But not successfully achieved in reducing the nutritional insecurity. The state of Punjab, which is considered India's breadbasket, has had historically higher levels of malnutrition than other less well-endowed areas of the country (World Bank, 2005). In the Green Revolution time, India's cereal production has increased but the poverty rate declined slowly (World Bank, 2007b). However, growth in staple crop production and levels of income has not triggered matching reductions in the incidence of chronic hunger and malnutrition. The number of chronically undernourished - people unable to meet their minimum food energy requirements (FAO, 2009d). The rapid urbanization in India is accompanied by a "double burden" of malnutrition and health hazards (UNICEF, 2012). On the other hand, the prevalence of overweight and obesity, and associated chronic diseases such as diabetes, is increasing among those slum dwellers who over-consume low-cost, high-energy and nutrient-poor foods (FAO, 2006b).

In India, the causes of persistent hunger and malnutrition are complex. It results in a combination of inadequacies in food access and availability, dietary knowledge, health, sanitation and care. People in low-income, 
food-insecure, resource-poor, socially excluded and economically marginalized households, in both rural and urban areas, are malnourished because they do not have enough resources to produce, or enough income to buy, sufficient amounts of all the foods they need.

In conclusion, nutritional security should be achieved through not only the quantity food items mainly quality food products. Important strategies to improve the nutrition security in India are promotion of Industrial fortified products, promotion of homestead gardening practices, snacks based food supplements for women of child-bearing age, enhancement of diversified agricultural production, empowerment of rural women, strengthening the links between the agriculture -nutrition and health sectors, providing nutrition education, ground water improvement climate change mitigation in agriculture for sustainable production, development of infrastructures in marginalized areas. Finally, India has many policies to control the food insecurity and malnutrition. The problem is with both design and implementation of the programmes.

India has many policies and programmes. However, food insecurity and malnutrition continue to be high. The problem is with both design and implementation of the programmes. Social mobilization, community participation and decentralized approach are necessary for better implementation of policies and programmes.

\section{References}

Arimond, M., Hawkes, C., Ruel, M.T., Sifri, Z., Berti, P.R., Leroy, J.L., Low, J.W., Brown, L.R. \& Frongillo, E.A. 2011. Agricultural interventions and nutrition: Lessons from the past and new evidence. In B. Thompson \& L.
Amoroso, eds. combating micronutrient deficiencies: Foodbased approaches, pp. 41-75. Rome, FAO and Wallingford, UK, CABI.

Chen, S., and Martin Ravallion. 2008. The developing world is poorer than we thought, but no less successful in the fight against poverty. Policy Research Working Paper 4703. August. The World Bank Group, Washington, DC.

Drèze, J. and A.Sen.2013. An uncertain glory: India and its contradictions. Princeton University Press. Princeton, New Jersey Government of India. 2013.

ECOSOC (United Nations Economic and Social Council). 2007. Strengthening efforts to eradicate poverty and hunger, including through the global partnership for development. Report of the Secretary-General. New York.

FAO. 2005. Non-wood forest products and nutrition. Appendix 4.1.2 of the report of the international expert consultation on non-wood forest products, Yogyakarta, 17-27 January 1995. Rome.

FAO. 2006b. the double burden of malnutrition: Case studies from six developing countries. FAO food and nutrition paper, No. 84. Rome. Sustainable nutrition security Restoring the bridge between agriculture and health

FAO. 2009b. How to feed the world in 2050 . Rome.

FAO. 2009d. the state of food insecurity in the world 2009: Economic crises impacts and lessons learned. Rome.

FAO. 2010. The state of food insecurity in the world 2010: Addressing food insecurity in protracted crises. Rome.

FAO. 2011a. Combating micronutrient deficiencies: Food-based approaches, by B. Thompson \& L. Amoroso, eds. Rome, FAO and Wallingford, UK, CABI. 
FAO. 2011b. Intra-household bargaining, gender roles in agriculture and how to promote welfare enhancing changes, by $\mathrm{H}$. Seebens. ESA Working Paper No. 11-10, March 2011. Rome.

Jose, S., and K. Navaneetham. 2010. Social infrastructure and women's undernutrition. Economic \& Political Weekly 45 (13) (27 March-2 April): 83-89.

Shah, T., Avinash Kishore, and Hemant Pullabhotla. 2009. Will the impact of the 2009 drought be different from 2002? Economic \& Political Weekly 44 (37): 11-14

Shivashankaran, D., Gurumurthy, S., Kehoe, S.H., Chheda, P.S., Margetts, B.M., Muley-Lotankar, P., Agarwal, A., Brown, N., Sahariah, S.A., Taskar, V., Fall, C.H.D. \& Potdar, R.D. 2011. Developing micronutrient-rich snacks for pre-conception and antenatal health: the Mumbai maternal nutrition project (MMNP). In B. Thompson \&
L. Amoroso, eds. combating micronutrient deficiencies: Foodbased approaches, pp. 214-223. Rome, FAO and Wallingford, UK, CABI.

UNICEF (United Nations Children's Fund). 2012. State of the world's children 2012: Children in an urban world. New York, USA.

UNSCN (United Nations Standing Committee on Nutrition). 2010a. Nutrition and the MDGs: Accelerating progress towards 2015. New York, USA.

World Bank. 2005. India's undernourished children: A call for reform and action, by M. Gragnolati, M. Shekar, M. Das Gupta, C. Bredenkamp \& Y.K. Lee. HNP discussion paper. Washington, DC, International Bank for Reconstruction and Development and World Bank. 2007b. World development report 2008. Washington, DC.

\section{How to cite this article:}

Muralikrishnan L., K.C. Sivabalan, V. Sangeetha and Premlata Singh. 2017. Nutrition Security Status in India - Impediments, Remedies and Way Forward. Int.J.Curr.Microbiol.App.Sci. 6(6): 220-226. doi: https://doi.org/10.20546/ijcmas.2017.606.026 